\title{
Mesures "techniques", mesures "morales"
}

De l'institution d'un habitant raisonnable face aux économies d'énergie

\section{Vololona Rabeharisoa}

\section{CpenEdition}

Journals

Édition électronique

URL : https://journals.openedition.org/tc/723

DOI : $10.4000 /$ tc. 723

ISSN : 1952-420X

Éditeur

Éditions de l'EHESS

\section{Édition imprimée}

Date de publication : 1 novembre 1991

ISSN : 0248-6016

\section{Référence électronique}

Vololona Rabeharisoa, " Mesures "techniques", mesures "morales" », Techniques \& Culture [En ligne],

16 | 1991, mis en ligne le 10 janvier 2006, consulté le 29 septembre 2022. URL : http://

journals.openedition.org/tc/723 ; DOI : https://doi.org/10.4000/tc.723

Ce document a été généré automatiquement le 29 septembre 2022.

Tous droits réservés 
Mesures "techniques", mesures "morales"

De l'institution d'un habitant raisonnable face aux économies d'énergie

Vololona Rabeharisoa 